\title{
CS-13 - Experiencias y percepción estudiantil al emplear un modelo de aula invertida (flipped classroom) en la Facultad de Agronomía de la Universidad de San Carlos de Guatemala
}

\author{
Experiences and student perceptions when using an flipped classroom model at the \\ Faculty of Agronomy de la Universidad de San Carlos de Guatemala \\ Byron Humberto González Ramírez1* y Ezequiel Abraham López Bautista2 \\ 1Centro de Telemática (CETE), 2Sub área de Métodos de Cuantificación e Investigación, Facultad de Agronomía, \\ Universidad de San Carlos de Guatemala
}

*Autor a quien se dirige la correspondencia: byrong.gt@gmail.com

\section{Resumen}

$\mathrm{D}$ esde su fundación en el año de 1950, en la Facultad de Agronomía de la Universidad de San Carlos se emplea como técnica de enseñanza predominante, la clase magistral. Durante el segundo semestre del año 2016 el Centro de Telemática (CETE) y la Sub área de Métodos de Cuantificación e Investigación empezaron a evaluar el uso de flipped classroom o aula invertida como patrón alternativo.Los propósitos principales fueron el describir la experiencia y percepción estudiantil al emplear aula invertida, además de identificar y describir las estrategias de aprendizaje estudiantil emergidas. Como sujetos de estudio se consideraron 25 estudiantes de un curso ordinario, quienes emplearon lecciones, libros y vídeos digitales en un sistema digital de gestión del aprendizaje, además de una aplicación para teléfonos inteligentes para estudiar los contenidos del curso previo a llegar al aula. Los resultados muestran que se alcanzó un máximo de $60 \%$ de visibilidad de los contenidos digitales en los sujetos de estudio. En términos de calificaciones no se encontró diferencias entre el modelo de clase magistral y aula invertida ( $p>0.05)$. Fue poco frecuente encontrar motivación individual al aprendizaje, autorregulación o metacognición en el modelo de aula invertida, además la estrategia cognitiva principal es la repetición. Sin embargo, los estudiantes reconocen que el aula invertida modifica el ambiente del salón de clase al permitir la escucha de la opinión de otros estudiantes y la discusión de temas con igual participación del profesor, resaltando esta condición como ventaja ante la pasividad estudiantil en el aula tradicional.

Palabras claves: Tecnologías de la información y la comunicación, multimedia, tecnología didáctica, educación virtual, motivación

\section{Abstract}

$\mathrm{T}$ he Faculty of Agronomy of the University of San Carlos uses since its foundation in the year of 1950 of routine way like model of teaching in the classroom the master class. During the second semester of 2016, the Telematics Center (CETE) and the Sub área of Quantification and Research Methods began to evaluate the use of flipped classroom or inverted classroom as an alternative pattern. The main purposes were to describe the experience and student perception of using inverted classroom, as well as to identify and describe the emergence of student learning strategies. As subjects of study were considered 25 students of an ordinary course, who used digital lessons, books and videos in a digital learning management system, as well as an application for smartphones to study the contents of the course prior to reaching the classroom. The results show that a maximum of $60 \%$ of digital content visibility was reached in the study subjects. In terms of grades, no difference was found between the master class and inverted classroom model ( $p>0.05)$. It was rare to find individual motivation to learn, self-regulation or metacognition in the inverted classroom model, and the main cognitive strategy is repetition. However, students recognize that the inverted classroom modifies the classroom environment by listening to the opinions of other students and discussing issues with equal participation of the teacher, highlighting this condition as an advantage over student passivity in the classroom traditional. 